\title{
Indirect Organogenesis and Plant Regeneration in Common Sage (Salvia officinalis L.): An Important Medicinal Plant of Iran
}

Samira Jafari ${ }^{1}$, Mohammad Hossein Daneshvar ${ }^{1}$, Mohammadreza Salehi Salmi ${ }^{1}$ \& Amin Lotfi Jalal-Abadi ${ }^{2}$

${ }^{1}$ Department of Horticulture Science, Ramin University of Agriculture and Natural Resources, Khoozestan, Iran

${ }^{2}$ Department of Agronomy, Ramin University of Agriculture and Natural Resources, Khoozestan, Iran

Correspondence: Mohammadreza Salehi Salmi, Department of Horticulture Science, Ramin University of Agriculture and Natural Resources, Khoozestan, Iran. Tel: 98-9177-016-178. E-mail: mrsalehisalmi@gmail.com

Received: January 22, 2017

doi:10.5539/mas.v11n5p22
Accepted: Fbruary 23, 2017

Online Published: April 8, 2017

URL: https://doi.org/10.5539/mas.v11n5p22

\begin{abstract}
Salvia species are an important resource for medicinal industry. This research was conducted to develop an indirect organogenesis regeneration protocol for Salvia officinalis L. via which callus was obtained from leaf and internode explants, among these explants internode explant gave best result on MS medium supplemented with $0.5 \mathrm{mg} / 1$ 6-Benzylaminopurine (BAP), $2.0 \mathrm{mg} / 1$ 1-Naphthaleneacetic acid (NAA). The maximum percentage $(70 \%)$ of regeneration was obtained with $0.5 \mathrm{mg}$ thidiazuron (TDZ) from internode explants. Shootlets were highly rooted on MS/2 medium added with $1.0 \mathrm{mg} / 1$ indole-3-butyric acid (IBA). In vitro rooted seedlings were successfully acclimatized. This in vitro regeneration system will facilitate further development of reliable procedures for this genus.
\end{abstract}

Keywords: indirect organogenesis, internode, Lamiaceae, regeneration

\section{Introduction}

Salvia officinalis L., Common sage, (family: Lamiaceae) one among the important medicinal plant species, is a perennial woody shrub native to the Mediterranean region, which is currently cultivated in several countries mostly to obtain the dried leaves to be used as raw material in medicine and perfumery industries ${ }^{28}$. Recent research has shown that sage essential oil can recover the memory and has shown promise in the treatment of Alzheimer's disease ${ }^{24}$. Application of plant extracts prepared from S. officinalis has a long tradition in human society, as this extract manifest remarkable biological effects (fungistatic, antibacterial, antioxidant, virustatic, analgesic) and have preventive and therapeutic activity against several diseases (e.g., bronchial asthma, inflammatory affection, atherosclerosis, cataracts, ischaemic heart disease, cancer, hepatotoxicity, insufficient sperm mobility). The antioxidant properties of $S$. officinalis reside typically in its phenolic nature ${ }^{2}$ and are designated in several researches and reviews. Lima et al. showed significant increase of the liver antioxidant enzyme glutathione-S-transferase activity in rats and mice of sage drinking clusters. Therefore, this herb is also a potential candidate to devise novel medicines to be applied in industry.

Conventionally, S. officinalis is propagated through seeds, however, in nature, seeds germinate slowly and remain dormant for a long time. Alternatively, cutting can be used but low population size hampers the process. Therefore, in vitro methods for large scale multiplication would be a viable option and has been reported for several medicinal herbs, which is considered a powerful tool to multi-ply difficult to propagate, rare or endangered and useful species for commercial cultivation as well conservation. Although, in vitro propagation of S. officinalis has been reported earlier, however, the clonal fidelity of the plants produced through these studies was not ascertained. Therefore, it is not clear whether the plants produced through these studies are genetically stable. The present study reports development of an efficient in vitro propagation protocol using internode explant and assessing the genetic stability of the regenerated plants.

\section{Materials and Methods}

\subsection{Seed Germination and Explant Preparation}

Seeds of Salvia officinalis L. were collected on December 2013 in Iran. The sage seeds were sterilized with 70\% ethyl alcohol for 30 seconds and after that solution of 5\% sodium hypochlorite solution for 5 minutes. Then the seeds were washed 5 times by sterile distilled water. Disinfected seeds were placed in $15 \mathrm{~cm}$ tube containing 5 $\mathrm{ml}$ solidified (agar) medium. The seeds were grown under optimal culture condition. 45 days old seedlings were 
used as explants and cut them into $10-15 \mathrm{~mm}$ fragment.

\subsection{Media and Culture Condition}

Basic culture was Murashige and Skoog medium. MS medium was supplemented with $30 \mathrm{~g} / 1$ sucrose (SigmaAldrich, USA) and solid with $8 \mathrm{~g} / \mathrm{l}$ agar (Sigma-Aldrich, USA), and the $\mathrm{pH}$ of the medium was adjusted to 5.7 \pm 0.2 with $0.1 \mathrm{~N} \mathrm{NaOH}$ or $0.1 \mathrm{~N} \mathrm{HCl}$ after adding of the plant growth regulators. The medium was dispensed in culture tube and autoclaved at $121^{\circ} \mathrm{C}$, for $30 \mathrm{~min}$. All the cultures were kept in a sterilized culture chamber at 25 $\pm 2^{\circ} \mathrm{C}$, with $60-65 \%$ relative humidity and $16 \mathrm{~h}$ photoperiods provided by cool white fluorescent light (55 $\mu$ molm $\left.\mathrm{s}^{-1}\right)$. The cultures were subcultured on the fresh medium after 20 days.

\subsection{Callus Initiation}

Explants including leaf $(0.5 \times 0.5 \mathrm{~cm})$ and internode $(1 \mathrm{~cm}$ in length), excised from 45 day old in vitro germinated plants, were placed horizontally on MS medium. In this test, the effects of auxins and cytokinin, both separately and in combination were investigated on callus initiation. Auxins such as 1-Naphthaleneacetic acid (NAA) and 2,4-dichlorophenoxyacetic acid (2,4-D) (1.0, 2.0 and $3.0 \mathrm{mg} / \mathrm{l})$, and cytokinin 6-Benzylaminopurine (BAP) $(5.0 \mathrm{mg} / \mathrm{l})$ were used. These culture conditions were used in all the tests stated below. Data of frequency (\%) of callus formation were noted after 45 days of culture.

\subsection{Shoot Organogenesis from Callus}

Well-established compact and hard callus, about $0.5 \mathrm{~g}$ fresh weight, was cultured on MS medium suplemented with BAP $(0.5 \mathrm{mg} / \mathrm{l})+\mathrm{NAA}(2.0 \mathrm{mg} / \mathrm{l})$ for shoot organogenesis. Calli were moved to shoot organogenesis media, containing of MS basal media added with TDZ $(0.1,0.5$ and $1.0 \mathrm{mg} / \mathrm{l})$ and BAP $(5,10$ and $25 \mathrm{mg} / \mathrm{l})$, in combinations of IBA at $0.5 \mathrm{mg} / \mathrm{l}$. Cultures were subcultured on fresh media after $25^{\text {th }}$ day of inoculation. The average number of shoots per inoculum and average length of shoot organogenesis from callus were noted on the $40^{\text {th }}$ day after moving the callus on shoot organogenesis media.

\subsection{Root Formation}

Regenerated shoots, with 2-4 cm long, were cultured on MS/2 basal medium supplemented with either of IBA or NAA $(0.1,0.5$ and $1.0 \mathrm{mg} / \mathrm{l})$ for adventitious rooting. Data were noted on percentage of rooting, length and number of the roots after 25 days of transmission onto the rooting media.

\subsection{Acclimatization of plantlets}

Rooted plantlets were gotten out from the medium and rinsed in sterile distilled water to remove all the traces of basal callus and agar. The plants were then transferring to plastic pots $(7 \mathrm{~cm}$ diameter) containing soil mixed of sand and vermiculite $(2: 1: 1)$. The pots were enclosed with polyethylene bags to maintain the $70-80 \%$ relative humidity. These plant were maintained at $25 \pm 2^{\circ} \mathrm{C}$ with light intensity of $25 \mu \mathrm{molm}^{-2} \mathrm{~s}^{-1}$ and $16-\mathrm{h}$ photoperiod for 15 days in the culture chamber, and the plants were then transferred to a shade $\left(50 \mu \mathrm{molm}^{-2} \mathrm{~s}^{-1}\right)$ in the third week. Plants were then transferred to glass house in the 30 days.

\subsection{Statistical Analyses}

The experimental design was a randomized complete with 4 replications. A replicate consisted of 25 explants. Data was statistically analyzed by using two-way ANOVA using IBM SPSS Statistics 22. Mean comparisons were made by least significant difference at the $5 \%$ probability level with Duncans's multiple range test.

\section{Results and Discussion}

\subsection{Effect Plant Growth Regulator Concentration and Types of Explant On Callus Initiation}

First experiment was set up to find out the most appropriate plant growth regulator concentration on callus formation (Fig. 1) and in vitro shoot organogenesis of $S$. officinalis L. were investigated in internode and leaf explants cultured on MS-basal media. The ratio of callus formation varied significantly $(\mathrm{P}<0.001)$, depending on the concentration of plant growth regulators present in the medium. Also results showed that a significant interaction between the two factors $(\mathrm{P}<0.001)$, indicating that the effects of explant types on in vitro callus formation percentage are dependent on plant growth regulator concentration. There was significant difference among the different explants types in terms of the callus formation percentage. Based on the results of this study, when NAA was added to the medium in combination with BAP, the percentage of callus formation was significantly increased (Fig. 1; Fig. 6, a). Likewise Rajeswari and Paliwal in Albizia odoratissima among the epicotyls, petiole, cotyledon segments tested, maximum of shoot regeneration percentage was obtained from epicotyls cultured on MS medium fortified with $1.5 \mathrm{mg} / 1 \mathrm{BAP}$, whereas the highest number of shoots per responding explant was recorded on medium containing $0.7 \mathrm{mg} / 1 \mathrm{BAP}$ and $0.1 \mathrm{mg} / 1 \mathrm{NAA}$. Similarly Gikloo et al. 
tested the different explants and obtained best result in leaf explants from Silybum marianum. In compare, among the hypocotyls, cotyledon, and root explants tested in Origanum vulgare, the best source for the production of modulated and compact callus were cotyledons explants. Likewise, Gurel et al. demonstrated that in Beta vulgaris, cotyledon and hypocotyls segments produced significantly more callus than leaf or petiole segments. The concentration of plant growth regulators required inducing a maximum percentage of callus induction varied with the type of explant. Results showed that Internode explants produced maximum callus (95\%) when cultured on MS medium fortified with NAA $(2.0 \mathrm{mg} / 1)$, BAP $(0.5 \mathrm{mg} / \mathrm{l})$, whereas in petiole explants, maximum callus production of $65 \%$ was also obtained when cultured on MS medium having same plant growth regulator (Fig. 1). Because of different segments have different endogenous level of plant growth hormone, differential responses may be accrued by different explant types on the same medium. Results of this experiment showed the Internode-derived callus was compact in texture, green in color, and grow fast, whereas the callus formed from leaf explants was friable in texture, green in color, and slow-growing. With regard to growth rates, the size of callus after 45 day of culture was greater from internode segments than that of leaf-derived callus.

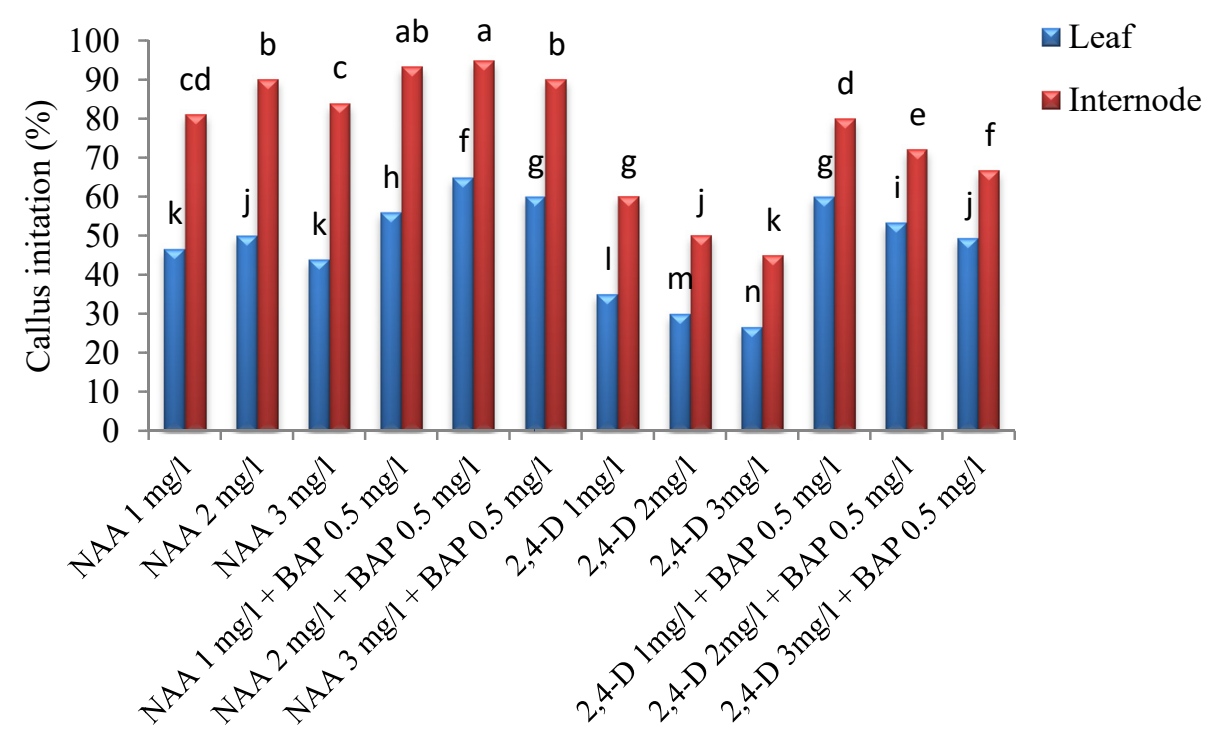

Figure 1. Callus initiation from various explants of 45 days old in vitro plants grown on MS medium fortified with auxins and cytokinin, after 45 days

\subsection{Shoot Organogenesis from Callus}

In the present study, poor shoot formation was obtained in leaf segments. Conversely, in internode segments, callus formation usually led to shoot organogenesis. In this research, data on shoot number and shoot regeneration percentage were documented after 45 days of culture. This study raises an interesting possibility for the stimulation of shoot regeneration (70\%) through internode segments cultured on MS medium containing 0.5 mg TDZ (Fig. 2; Fig. 6, b and c). However, in the present study we found that explant types could not influence on shoot regeneration percentage significantly. Likewise Thakur et al. obtained $75 \%$ shoot regeneration frequency in Populus deltoides using petiole explants. Internode was suitable explants that regenerated the higher shoots (2.5) compared to leaf explants. The pioneering work of Gubis et al. ${ }^{9}$ epicotyl and hypocotyl have been considered the optimal explants for shoot regeneration in Lycopersicon esculentum while cotyledons showed a poor response on regeneration medium containing $1 \mathrm{mg} / \mathrm{l}$ zeatin and $0.1 \mathrm{mg} / \mathrm{l} \mathrm{IAA}$. Molina also noted that stems and petioles explants of Salvia canariensis produced the maximum shoot regeneration rate whereas it was observed that stem was found poor efficient regeneration medium contain $4.44 \mu \mathrm{M}$ BAP and NAA $\mu \mathrm{M}$. Likewise Martin et al.reported that leaf and internode explants of Ophiorrhiza prostrate produced the maximum shoot regeneration in high range of BAP in the MS medium. Anuradha and Pullaiah ${ }^{1}$ used shoot tip, node and mesocotyl explants for direct shoot regeneration, whereas present experiment leaf, internode and petiole explants were used for shoot regeneration through callus formation. Moreover glutamine, sodium citrate, adenine and adenine sulfate was discussed in this experiment. 


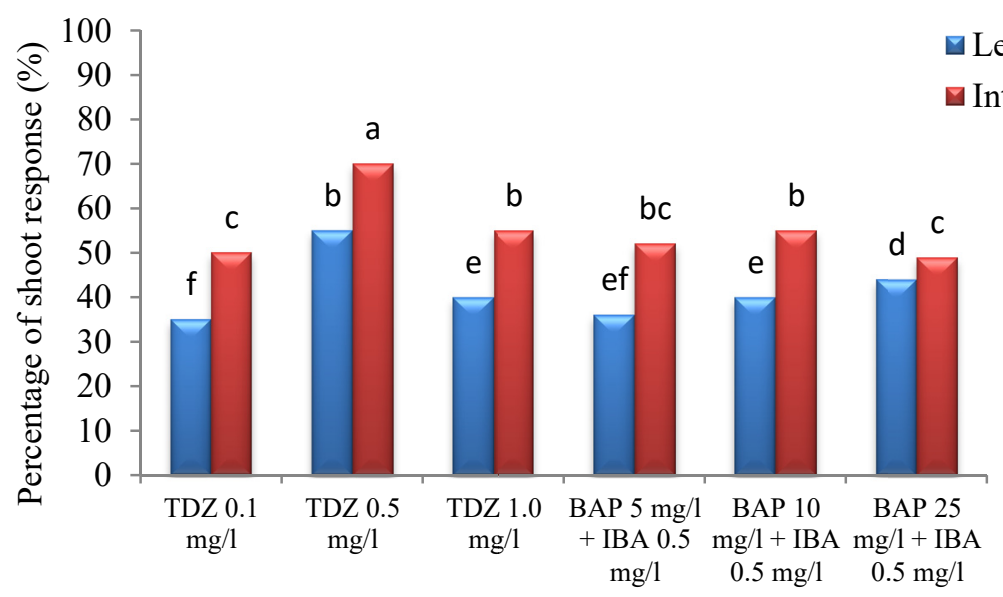

Figure 2. Shoot regeneration response from 45 days old in vitro plants grown on MS medium fortified with plant growth regulators

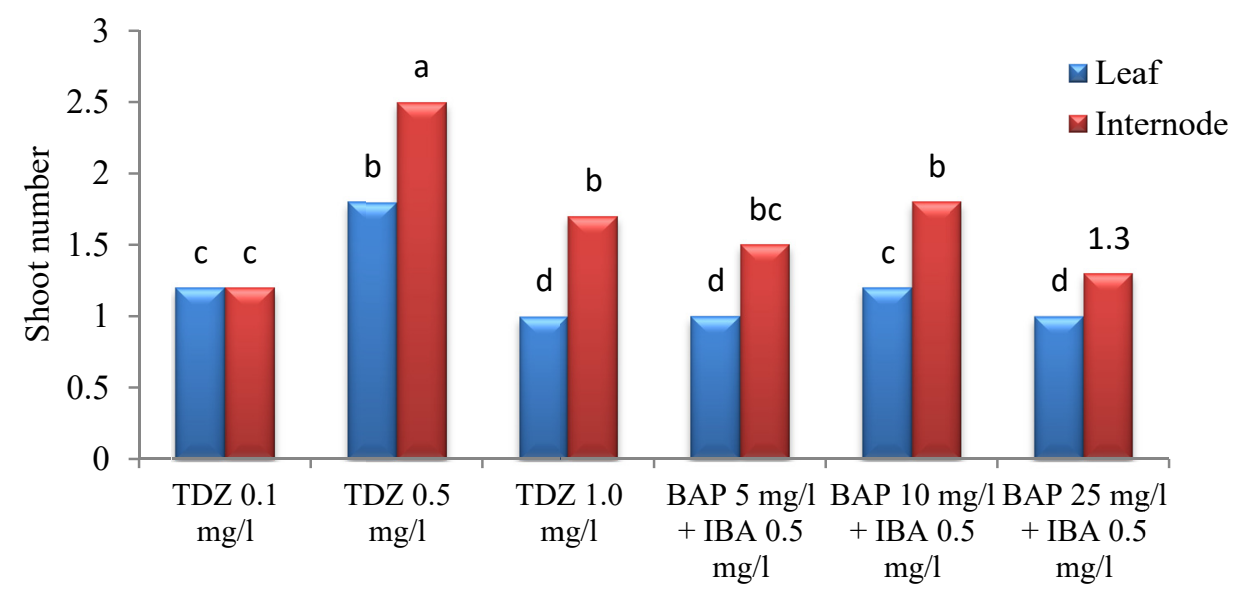

Figure 3. Shoot number response from 45 days old in vitro plants grown on MS medium fortified with plant

\subsection{Rooting of Regenerated Shoots}

growth regulators

The elongated shoots were transferred to MS/2 medium fortified with different concentrations of NAA and IBA for root induction. 45 day after inoculation, number of roots per shoot and percentage of shoot forming roots were recorded. In the present study, rooting technique was followed for inducing roots from shoots regenerated from internode and leaf segments. Shoots formed root after 20 days in most of the treatments. However, the data for the percentage of rooted shoots and the amount of roots were recorded after stated time. The present investigation proved that differences of root forming of micro shoots collected from internodes and leaf explants were not significantly, but the maximum number of roots (3.9) the and maximum percentage of rooting (72) were observed in the shoots obtained from internode segments (Fig. 4; Fig 5; Fig 6, d). MS/2 basal media supplemented with high concentration of IBA favored better in vitro rooting for internode derived calluogenesis. Likewise Pandey and Sushma obtained more roots using IBA for rooting of Quercus leucotrichophora. While NAA caused weak root forming with callusing at the base (data not shown). A similar response was also observed by Shriram et al. in Helicteres isora. 


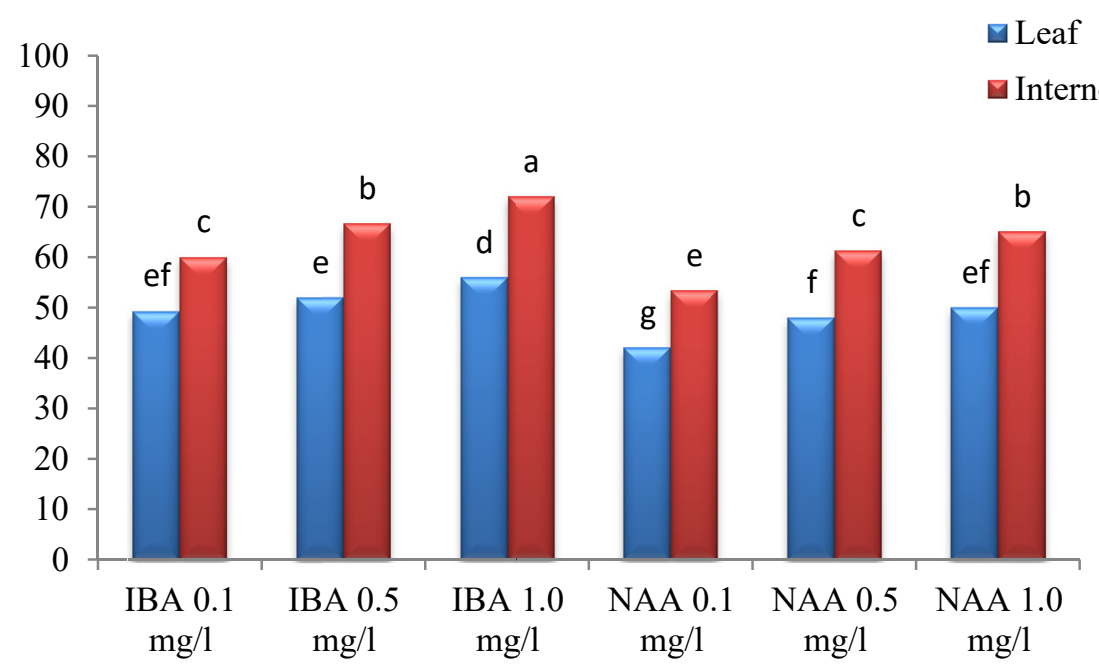

Figure 4. Response of rooting of in vitro raised shoots from 45 days old in vitro plants cultured on MS media furtified with auxins, after 45 days

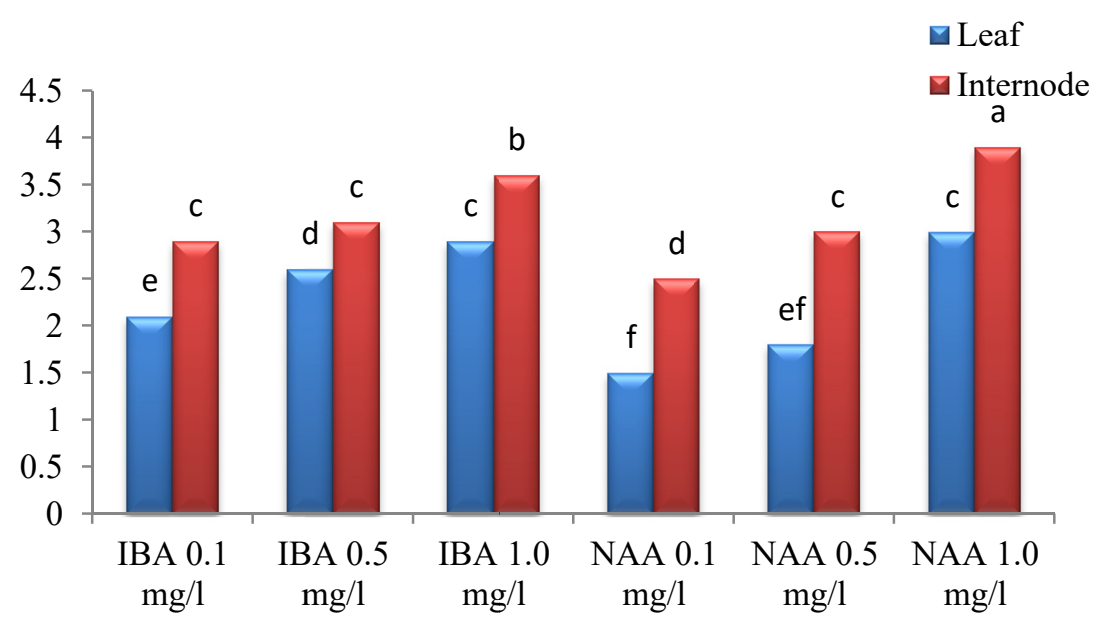

Figure 5. Response of root number of in vitro raised shoots from 45 days old in vitro plants cultured on MS

media furtified with auxins, after 45 days

\subsection{Acclimatization}

Plantlets, after transplanting to soil, sand and vermiculite mix (2:1:1) and were subjected to culture chamber under polyethylene sheets for 30 days. Gradual removal of polyethylene sheets, so as to lower down the high atmospheric humidity slowly, was observed as an effective technique for the hardening procedure as more than $80 \%$ of the plantlets survived via this. Plantlets were irrigated with MS/4 medium without sucrose and meso-inositol at 3 days intervals for a period of 20 days (Fig 6, e). The acclimatization plantlets were then transferred to pots containing soil and kept in the shaded greenhouse for another 5 weeks. Next, the plantlets were transplanted to soil conditions where plants had a 95\% survival rate in field (Fig 6, f). Likewise Chauhan et al. obtained $100 \%$ survival in in vitro raised plantlet of Garcinia indica. Plants propagated through in vitro method, in the high atmospheric humidity; their leaves had great spaces between cells palisades and few stomates. Rajeswari and Paliwal found, Albizia odoratissima, the maximum (75\%) of survival of the plant after hardening in pots containing vermiculite, while Ndiaye et al. reported $100 \%$ of survived plantlets of Bambusa vulgaris after hardening in sterile perlite-peat substrate. The so rooted plantlets subsequently were transferred to larger pots containing the same soil and moved to greenhouse after 4 weeks. The obtained plants did not show detectable variation in morphological or growth characteristics compared with the donor plants. 

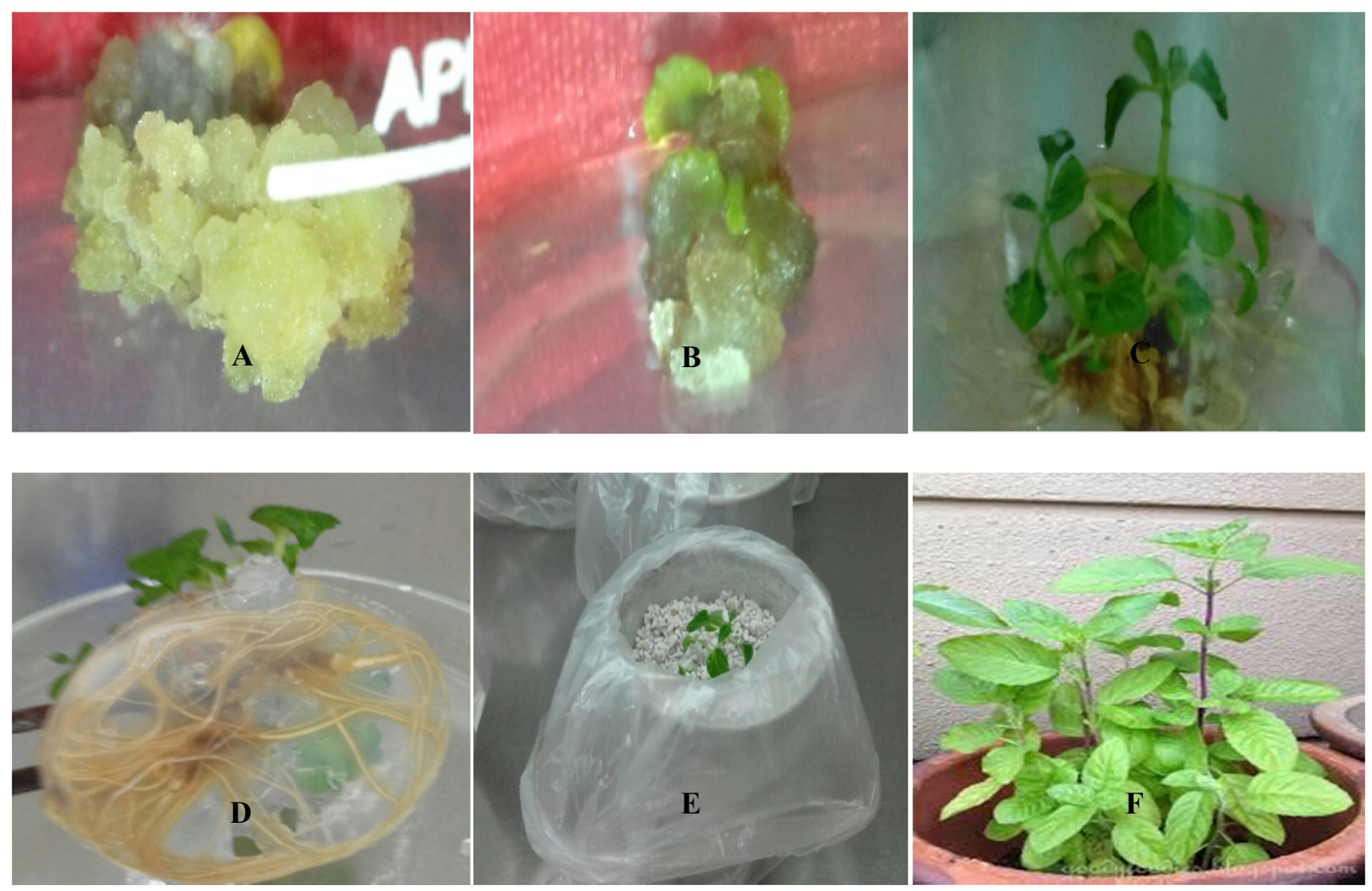

Figure 6. Regeneration phases during indirect organogenesis in Salvia officinalis L

\subsection{Acclimatization}

Plantlets, after transplanting to soil, sand and vermiculite mix (2:1:1) and were subjected to culture chamber under polyethylene sheets for 30 days. Gradual removal of polyethylene sheets, so as to lower down the high atmospheric humidity slowly, was observed as an effective technique for the hardening procedure as more than $80 \%$ of the plantlets survived via this. Plantlets were irrigated with MS/4 medium without sucrose and meso-inositol at 3 days intervals for a period of 20 days (Fig 6, e). The acclimatization plantlets were then transferred to pots containing soil and kept in the shaded greenhouse for another 5 weeks. Next, the plantlets were transplanted to soil conditions where plants had a $95 \%$ survival rate in field (Fig 6, f). Likewise Chauhan et al. obtained $100 \%$ survival in in vitro raised plantlet of Garcinia indica. Plants propagated through in vitro method, in the high atmospheric humidity; their leaves had great spaces between cells palisades and few stomates. Rajeswari and Paliwal found, Albizia odoratissima, the maximum (75\%) of survival of the plant after hardening in pots containing vermiculite, while Ndiaye et al. reported $100 \%$ of survived plantlets of Bambusa vulgaris after hardening in sterile perlite-peat substrate. The so rooted plantlets subsequently were transferred to larger pots containing the same soil and moved to greenhouse after 4 weeks. The obtained plants did not show detectable variation in morphological or growth characteristics compared with the donor plants.

\section{Conclusion}

Here, we demonstrated an efficient adventitious shoot formation, rooting, and hardening off protocols for Salvia officinalis $\mathrm{L}$. accessible a principal stage in developing technologies for the clonal propagation and possible gene transfer of this species. It was found that, of the seedling segments studied, internode had a higher potential for shoot organogenesis than leaf. In addition, the orientation of explants on media and growth regulator conditions affected the organogenic efficiency of internode segments. This may realize the demand of fiber industries and minimize the impact of over exploitation of the plants. Besides the propagation of elite cultivars and conservation of this endangered and economical plant, a highly efficient regeneration procedure opens a method for progress of the plant through genetic transformation strategies.

\section{References}

Anuradha, T., \& Pullaiah, T. (2001). Effect of Hormones on the Organogenesis and the Somatic Embryogenesis 
of an Endangered Tropical Forest Tree-Hildegardia populifolia (Roxb.) Schott. \& Endl. Taiwania. https://doi.org/10.6165/tai.2001.46(1).62

Baricevic, D., \& Bartol, T. (2000). The biological/pharmacological activity of the Salvia genus. In S. E. Kintzios (Ed.), Sage: The genus Salvia (pp. 143-184). Amsterdam: Harwood Academic Publishers.

Brainerd, K. E., \& Fuchigami, L.J. (1981). Acclimatization of aseptically cultured apple plants to low relative humidity. Journal of American Society of Horticulture Science, 106, 515-518.

Chandra, B., Palni, L. M. S., \& Nandi, S. K. (2006). Propagation and conservation of Picrorhiza kurroa Royle ex Benth.: an endangered Himalayan medicinal herb commercial value. Biodiversity and Conservation https://doi.org/10.5897/JMPR12.115

Chauhan, D. K., Thakur, A. K., Dass, A., Lima, J. M., \& Malik, S. K. (2012). Direct organogenesis from leaf explants of Garcinia indica Choisy: An important medicinal plant. Indian Journal of Biotechnology, 11, 215-219.

Cuenca, S., \& Amo-Marco, J. B. (2000). In vitro propagation of two Spanish endemic species of Salvia through bud proliferation. In Vitro Cellular Development Biology Plant. https://doi.org/10.1007/s11627-000-0042-2

Gikloo, T. S., Elhami, B., \& Khosrowchahli, M. (2012). Effects of explants type, plant growth regulators and activated charcoal on direct organogenesis of Silybum marianum. African Journal of Biotechnology. https://doi.org/10.5897/AJB12.361

Giri, L., Jugran, A., Dhyani, P., Rawal, R. S., Rawat, S., Andola, H., Bhatt, I. D., \& Dhar, U. (2012). In vitro propagation, genetic and phytochemical assessment of Habenaria edgeworthii: an important Astavarga plant. Acta Physiologiae Plantarum. https://doi.org/10.1007/s11738-011-0884-8

Gubis, J., Lajchova, Z., Furage, J., \& Jurekova, Z. (2003). Effect of genotype and explant type on shoot regeneration in tomato (Lycopersicon esculentum Mill.) in vitro. Czech Journal of Genetics and Plant Breeding. https://doi.org/10.1.1.486.9279

Gurel, S., Gurel, E., \& Kaya, Z. (2001). Callus development and indirect shoot regeneration from seedling explants of sugar beet (Beta vulgaris L.) cultured in vitro. Turkish Journal of Botany. https://doi.org/10.1.1.473.9463\&rep=rep1

Lima, C. F., Andrade, P. B., Seabra, R. M., Fernandes-Ferreira, M., \& Pereira-Wilson, C. (2005). The drinking of a Salvia officinalis infusion improves liver antioxidant status in mice and rats. Journal of Ethnopharmacology. https://doi.org/10.1016/j.jep.2004.11.029

Martin, K. P., Shahanaz Beegum, A., Zhang, C., Madhusoodanan, P. V., Slater, A., \& Ligimol Nishitha, I. K. (2007). Organogenesis from leaf and internode explants of Ophiorrhiza prostrata, an anticancer drug (camptothecin) producing plant. Electronic Journal of Biotechnology. https://doi.org/10.2225/vol10

Molina, S. M. (2004). In vitro callus induction and plants from stem and petiole explants of Salvia canariensis L. Plant Tissue Culture. https://doi.org/10.1.1.549.3581

Morimoto, S., Goto, Y., \& Shorama, Y. (1994). Production of lithospermic acid B and rosmarinic acid in callus tissue and regenerated plantlets of Salvia miltiorrhiza. J. Nat. Prod, 57(6), 817-823.

Murashige, T., \& Skoog, F. (1962). A revised medium for rapid growth and bioassays with tobacco tissue cultures. Physiol. Plant, 15, 473-497.

Nadeem, M., Palni, L. M. S., Purohit, A. N., Pandey, H., \& Nandi, S. K. (2000). Propagation and conservation of Podophyllum hexandrum Royle: an important medicinal herb. Biological Conservation, 92, 121-129.

Ndiaye, A., Diallo, M. S., Niang, D., \& Gassama-Dia, Y. K. (2006). In vitro regeneration of adult trees of Bambusa vulgaris. African Journal of Biotechnology. https://doi.org/10.5897/AJB06.149

Neena, K., \& Pardha Sarathi, P. (1992). Regeneration of plants from callus cultures of Origanum vulgare L. Plant Cell Reports, 11, 476-479.

Oliveira, F. Q., Gobira, B., Guimaraes, C., Batista, J., Barreto, M., \& Souza, M. (2007). Especies vegetais indicadas na odontologia. Rev. Bras. Farmacogn. https://doi.org/10.1590/S0102

Olszowska, O., \& Furmanowa, M. (1990). Micropropagation of Salvia officinalis by shoot buds. Planta Med, 56, 637-641.

Pandey, A., \& Sushma, T. (2012). Influence of kinetin on in vitro rooting and survival of banj oak (Quercus 
leucotrichophora L.). African Journal of Biotechnology. https://doi.org/10.5897/AJB12.161

Pandey, H., Nandi, S. K., Kumar, A., Palni, U. T., Chandra, B., \& Palni, L. M. S. (2004). In vitro propagation of Aconitum balfourii Stapf.: an important aconite of the Himalayan alpines. Journal of Horticulture Science and Biotechnology. https://doi.org/10.1080/14620316.2004.11511733

Penso, G. (1983). Index Plantarum Medicinalium Totius Mundi Eorumque Synonymorum. OEMF, Milano.

Perry, E. K., Pickering, A. T., Wang, W. W., Houghton, P. J., \& Perry, N. S. L. (2005). Medicinal plants and Alzheimer's disease: from ethnobotany to phytotherapy. J. Pharm. Pharmacol. 51, 527-534

Quoirin, M., Bittencourt, M. J., Zanette, F., \& De Oliveria, D. E. (1998). Effect of growth regulators on indirect organogenesis of Acacia mearnsii tissues cultured in vitro. Revista Brasileira de Fisiologia Vegetal. https://doi.org/10.1.1.468.9721

Rajeswari, V., \& Paliwal, K. (2008). In vitro adventitious shoot organogenesis and plant regeneration from seedling explants of Albizia odoratissima L.F. (Benth.) In Vitro Cellular and Development Biology Plant. http://dx.doi.org/10.1007/s11627-008-9120-7

Rout, G. R., Samantaray, S., \& Das, P. (2000). In vitro manipulation and propagation of medicinal plants. Biotechnology Advances. https://doi.org/10.1016/S0734-9750(99)00026-9

Santos-Gomes, P. C., Seabra, R. M., Andrade, P. B., \& Fernandes-Ferreira, M. (2002). Phenolic antioxidant compounds produced by in vitro shoots of sage (Salvia officinalis L.). Plant Sci. https://doi.org/10.1016/S0168-9452(02)

Shan, B., Cai, Y. Z., Sun, M., \& Corke, H. (2005). Antioxidant capacity of 26 spice extracts and characterization of their phenolic constituents. Journal of Agricultural and Food Chemistry. https://doi.org/10.1021/jf051513y

Shriram, V., Kumar, V., \& Shitole, M. G. (2008). Indirect organogenesis and plant regeneration in Helicteres isora L., an important medicinal plant. In Vitro Cellular \& Developmental Biology-Plant. https://doi.org/10.1007/s11627-008-9108-3

Slamenova, D., Horvathova, E., Sramkova, M., \& Labaj, J. (2007). Toxic genotoxic and DNA-protective effects of selected plant volatiles on human cells cultured in vitro. In Z.D urackova \& S. Knasmuller (Eds.), The activity of natural compounds in diseases prevention and therapy (pp. 149-170). Mind \& Health Civil Association, Slovak Academic Press Ltd.

Thakur, A. K., Saraswat, A., \& Srivastava, D. K. (2012). In vitro plant regeneration through direct organogenesis in Populus deltoides clone G48 from petiole explants. Journal of Plant Biochemistry and Biotechnology. https://doi.org/10.1007/s13562-011-0067-0

Zheng, W., \& Wang, S. Y. (2001). Antioxidant activity and phenolic compounds in selected herbs. Journal of Agricultural and Food Chemistry. https://doi.org/10.1021/jf010697n

\section{Copyrights}

Copyright for this article is retained by the author(s), with first publication rights granted to the journal.

This is an open-access article distributed under the terms and conditions of the Creative Commons Attribution license (http://creativecommons.org/licenses/by/4.0/). 